\title{
Penerapan Model Pembelajaran Ttw (Think Talk Write) Dalam Meningkatkan Hasil Belajar Siswa Kelas X Iis 1 SMA Negeri 2 Kulisusu Pada Mata Pelajaran Geografi
}

\author{
Trisna Wati ${ }^{1}$, Sitti Kasmiati ${ }^{2}$, La Ode Nursalam ${ }^{3}$ \\ 123 JURUSAN PENDIDIKAN GEOGRAFI / FAKULTAS KEGURUAN DAN ILMU \\ PENDIDIKAN / UNIVERSITAS HALUOLEO \\ Email : watit795@gmail.com
}

(Received: Agustus 2019; Reviewed: Agustus 2019; Accepted: September 2019; Published: Oktober 2019)

\begin{abstract}
SMA Negeri 2 Kulisusu is one of the schools in North Buton Regency which is the object of research by researchers because student learning outcomes are still low. The purposes of this study are: (1) To see a picture of student learning activities through the application of the Think Talk Write (TTW) learning model in class $X$ IIS 1 of SMA Negeri 2 Kulisusu; (2) To see the description of teacher teaching activities through the application of the Think Talk Write (TTW) learning model in class X IIS 1 of SMA Negeri 2 Kulisusu; (3) To see a picture of an increase in the learning outcomes of grade X IIS 1 students at SMA Negeri 2 Kulisusu by using the Think Talk Write learning model. The data in this study are qualitative and quantitative data obtained from observation sheets and learning outcomes tests. Based on the results of data analysis, it was found that: (1) in the first cycle the average score of student learning activities was 2,4 which was categorized sufficiently increased in the second cycle to 3,6 which was categorized as good; (2) in the first cycle the average score of the teaching activities of the teachers was 2,5 which was categorized sufficiently increased in the second cycle to 3,6 which was categorized as good; and (3) an increase in geography learning outcomes of students of class X IIS 1 of SMA Negeri 2 Kulisusu from cycle I to cycle II. In the first cycle showed that 21 students who scored $\geq 75$ with an average value of 75,3. Furthermore, the results of the second cycle test showed a significant increase because there were 28 students who scored $\geq 75$ with an average score of 81,3.
\end{abstract}

Key words: Think Talk Write, Learning Outcome, SMAN 2 Kulisusu

\section{ABSTRAK}

SMA Negeri 2 Kulisusu merupakan salah satu sekolah di Kabupaten Buton Utara yang menjadi objek penelitian peneliti karena hasil belajar siswa yang masih rendah. Tujuan penelitian ini adalah: (1) Untuk melihat gambaran aktivitas belajar siswa melalui penerapan model pembelajaran Think Talk Write (TTW) pada kelas X IIS 1 SMA Negeri 2 Kulisusu; (2) Untuk melihat gambaran aktivitas mengajar guru melalui penerapan model pembelajaran Think Talk Write (TTW) 


\begin{abstract}
pada kelas X IIS 1 SMA Negeri 2 Kulisusu; (3) Untuk melihat gambaran peningkatan hasil belajar geografi siswa kelas X IIS 1 SMA Negeri 2 Kulisusu dengan menggunakan model pembelajaran Think Talk Write. Data dalam penelitian ini adalah data kualitatif dan kuantitatif yang diperoleh dari lembar observasi dan tes hasil belajar. Berdasarkan hasil analisis data diperoleh bahwa: (1) pada siklus I skor rata-rata aktivitas belajar siswa adalah 2,4 yang berkategori cukup meningkat pada siklus II menjadi 3,6 yang berkategori baik; (2) pada siklus I skor rata-rata aktivitas mengajar guru adalah 2,5 yang berkategori cukup meningkat pada siklus II menjadi 3,6 yang berkategori baik; dan (3) terjadi peningkatan hasil belajar geografi siswa kelas X IIS 1 SMA Negeri 2 Kulisusu dari siklus I ke siklus II. Pada siklus I menunjukan bahwa 21 siswa yang memperoleh nilai $\geq 75$ dengan nilai rata-rata sebesar 75,3. Selanjutnya, hasil tes siklus II menunjukan peningkatan yang cukup signifikan karena terdapat 28 siswa yang memperoleh nilai $\geq 75$ dengan nilai rata-rata 81,3 .
\end{abstract}

Kata Kunci: Think Talk Write, Hasil Belajar, SMAN 2 Kulisusu

\title{
PENDAHULUAN
}

Belajar adalah suatu proses usaha yang dilakukan seseorang untuk memperoleh suatu perubahan tingkah laku yang baru secara keseluruhan, sebagai hasil pengalamannya sendiri dalam interaksi dengan lingkungannya (Slameto, 2011). Pada dasarnya proses belajar ditandai dengan terjadinya perubahan pada diri siswa, baik dalam aspek Kognitif, Afektif, maupun Psikomotor. Perubahan itu meliputi cara berpikir, cara pengendalian diri juga cara pengendalian berinteraksi dengan orang lain dan terhadap pekerjaan. Perubahan perilaku dalam aspek kognitif tercermin dari hasil belajar. Hasil belajar merupakan pengukuran dari penilaian kegiatan belajar atau proses belajar yang dinyatakan dalam symbol, huruf maupun kalimat yang menceritakan hasil yang sudah dicapai oleh setiap anak pada periode tertentu. Perubahan yang terjadi pada diri siswa, baik yang menyangkut aspek kognitif, afektif, dan psikomotor sebagai hasil dari belajar (Susanto, 2013). Hasil belajar dipengaruhi oleh beberapa faktor, baik yang bersifat internal mapun eksternal. Faktor-faktor yang mempengaruhi hasil belajar antara lain meliputi faktor internal dan faktor eksternal. Faktor internal meliputi faktor fisiologis dan faktor psikologis. Sementara faktor eksternal meliputi faktor lingkungan dan faktor instrumental. (Rusman, 2013)

Rendahnya hasil belajar siswa pada mata pelajaran geografi di SMA merupakan indikasi bahwa selama ini proses pembelajaran yang dilakukan di sekolah-sekolah belum optimal, sehingga perlu adanya suatu upaya untuk meningkatkannya. Berdasarkan hasil pengamatan diperoleh informasi bahwa pelaksanaan proses pembelajaran Geografi di SMA Negeri 2 Kulisusu, khususnya kelas X IIS 1 menggunakan metode atau pendekatan pembelajaran konvensional dan satu arah. Akibatnya, siswa merasa bosan dan kurang memahami pelajaran geografi yang disampaikan sehingga hasil belajar siswa masih rendah dan belum memenuhi kriteria ketuntasan belajar. Hasil belajar siswa kelas X IIS 1 yang dinyatakan tuntas belajar yaitu $62,5 \%$ atau 20 orang siswa, sedangkan yang lainnya yaitu sebanyak 12 orang siswa atau 37,5\% belum mencapai Kriteria Ketuntasan Minimal (KKM) yang ditetapkan sekolah yaitu 75. Melihat fakta-fakta yang dipaparkan tersebut, perlu adanya perbaikan pembelajaran dalam kelas. Rendahnya aktivitas dan hasil belajar serta berbagai masalah di atas dipengaruhi oleh banyak faktor. 
Pemilihan model pembelajaran yang tepat dapat membantu guru mengatasi masalahmasalah tersebut, sehingga tujuan dalam pelaksanaan pembelajaran dapat tercapai. Guru dapat menggunakan model pembelajaran Think Talk Write (TTW) untuk membuat siswa lebih aktif dalam pembelajaran dan hasil belejar siswa meningkat (Suhendar, 2011).

TTW merupakan model pembelajaran yang didasarkan pada pemahaman bahwa belajar adalah sebuah perilaku sosial. Model pembalajaran ini dikenalkan oleh Huinker dan Laughin, "pada dasarnya (model pembelajaran) ini dibangun melalui berpikir, berbicara, dan menulis" (Huda, 2013).

Alur kemajuan pembelajaran TTW dimulai dari keterlibatan siswa dalam berpikir atau berdialog dengan dirinya sendiri setelah proses membaca, selanjutnya berbicara dan membagi ide dengan temannya sebelum menulis. Suhendar (2011) mengemukakan bahwa model pembelajaran TTW "pada dasarnya menggunakan strategi pembelajaran kooperatif, sehingga dalam pelaksanaannya model ini membagi sejumlah siswa ke dalam kelompok kecil secara heterogen agar suasana pembelajaran lebih efektif".

Penerapan model pembelajaran TTW memiliki sejumlah kelebihan di antaranya: 1) Mempertajam seluruh keterampilan berpikir visual. 2) Mengembangkan pemecahan yang bermakna dalam rangka memahami materi ajar. 3) Dengan memberikan soal open ended dapat mengembangkan keterampilan berpikir kritis dan kreatif siswa. 4) Dengan berinteraksi dan berdiskusi dengan kelompok akan melibatkan siswa secara aktif dalam belajar. 5) Membiasakan siswa berpikir dan berkomunikasi dengan teman, guru, dan bahkan dengan diri mereka sendiri. Adapun kelemahan penggunaan model pembelajaran TTW, antara lain: 1) Ketika siswa bekerja dalam kelompok itu mudah kehilangan kemampuan dan kepercayaan, karena didominasi oleh siswa yang mampu. 2) Guru harus benar-benar menyiapkan semua media dengan matang agar dalam menerapkan model pembelajaran ini tidak mengalami kesulitan (Hamdayana, 2014),

Berdasarkan uraian di atas maka fokus penelitian ini adalah "Penerapan Model Pembelajaran TTW (Think Talk Write) Dalam Meningkatkan Hasil Belajar Siswa kelas X IIS 1 SMA Negeri 2 Kulisusu Pada Mata Pelajaran Geografi”.

\section{METODE}

Jenis penelitian ini menggunakan metode Penelitian Tindakan Kelas (classroom activities research). Agung (2012: 63) menyatakan bahwa PTK adalah jenis penelitian untuk menyelesaikan masalah pembelajaran di kelas secara cermat dan sistematis untuk meningkatkan kualitas pembelajaran. PTK ini dilakukan dengan menerapkan model pembelajaran Think Talk Write (TTW) sebagai alternatif tindakan untuk meningkatkan hasil belajar geografi siswa kelas $X$ IIS 1 SMA Negeri 2 Kulisusu pada materi pokok dinamika atmosfer dan dampaknya terhadap kehidupan.

\section{Tempat dan Waktu Penelitian}

Penelitian ini dilaksanakan di SMA Negeri 2 Kulisusu, Jl.Kopasarano No....Lemo, Kecamatan Kulisusu, Kabupaten Buton Utara. Penelitian ini dilaksanakan pada semester genap tahun pelajaran 2018/2019.

\section{Subjek Penelitian}

Subjek penelitian tindakan kelas ini adalah siswa kelas X IIS 1 SMA Negeri 2 Kulisusu tahun pelajaran 2018/2019 dengan jumlah 31 orang siswa, terdiri dari 18 orang siswa laki-laki dan 13 orang siswi perempuan.

\section{Teknik Analisis Data}


Trisna Wati, 2019, Penerapan Model Pembelajaran Ttw (Think Talk Write) Dalam Meningkatkan Hasil Belajar Siswa Kelas X Iis 1 Sma Negeri 2 Kulisusu Pada Mata Pelajaran Geografi

Data yang diperoleh dalam penelitian ini, dianalisis menggunakan analisis deskriptif kualitatif dan kuantitatif. Analisis deskriptif kualitatif digunakan untuk memberikan penjelasan mengenai hasil observasi aktivitas siswa dan aktivitas guru selama proses belajar mengajar berlangsung, sedangkan analisis deskriptif kuantitatif digunakan untuk menyajikan gambaran tentang hasil belajar siswa. Teknik analisis data tersebut dirumuskan sebagai berikut:

1. Menentukan skor rata-rata hasil belajar siswa dengan menggunakan rumus:

$$
\bar{X}=\frac{\sum_{i=1}^{n} X_{i}}{n} \quad(\text { Sudjana 2011) }
$$

Keterangan:

$\bar{X}=$ nilai rata-rata yang diperoleh siswa

$X_{i}=$ nilai yang diperoleh tiap siswa

$\mathrm{n}=$ Jumlah item aktivitas siswa

2. Menentukan nilai siswa ditentukan berdasarkan skor yang diperoleh siswa pada tes yang dilakukan dengan rumus:

$$
N=\frac{\text { skor yang diperoleh siswa }}{\text { skor maksimum }} \times 100
$$

Keterangan:

$\mathrm{N}=$ nilai yang dicari atau diharapkan

$$
100=\text { bilangan tetap } \quad \text { (Sudjana, 2011) }
$$

3. Menghitung nilai rata-rata hasil belajar kelas menggunakan rumus:

$$
\bar{X}=\frac{\sum X}{\sum N}
$$

Keterangan:

$\bar{X}=$ nilai rata-rata

$\sum X=$ jumlah nilai yang diperoleh siswa

$\sum N=$ banyaknya siswa $\quad$ (Sudjana, 2011)

4. Persentase ketuntasan belajar siswa secara keseluruhan, dapat dicari dengan rumus sebagai berikut:

$$
P=\frac{\sum \text { siswa yang tuntas belajar }}{\sum \text { siswa }} \times 100 \%
$$

Keterangan:

$\mathrm{P}=$ presentase ketuntasan belajar siswa secara keseluruhan

$\Sigma=$ jumlah $\quad$ (Sudjana, 2011: 41)

5. Presentase jumlah siswa yang belajarnya sudah tuntas, dengan menggunakan rumus:

Keterangan:

$$
\% \text { tuntas }=\frac{\sum T B}{N} \times 100 \%
$$

$\sum T B=$ jumlah siswa yang tuntas belajar

$N=$ jumlah siswa secara keseluruhan

(Sudjana,2011) 
Trisna Wati, 2019, Penerapan Model Pembelajaran Ttw (Think Talk Write) Dalam Meningkatkan Hasil Belajar Siswa Kelas X Iis 1 Sma Negeri 2 Kulisusu Pada Mata Pelajaran Geografi

6. Mengklasifikasikan rata-rata aktivitas siswa dalam kategori sebagai berikut:

$1 \leq \mathrm{Xi}<2$ : Kurang

$2 \leq \mathrm{Xi}<3:$ Cukup

$3 \leq \mathrm{Xi}<4$ : Baik

$\mathrm{Xi}=4:$ Sangat Baik $\quad$ (Sudjana, 2011)

\section{HASIL DAN PEMBAHASAN}

\section{Hasil}

\section{Pelaksanaa Tindakan Siklus I}

\section{Aktivitas Siswa Pertemuan I dan II Siklus I}

Gambaran rata-rata aktivitas belajar siswa melalui penerapan model pembelajaran TTW pada siklus I pada pertemuan I dan II dapat dilihat pada gambar 1 berikut:

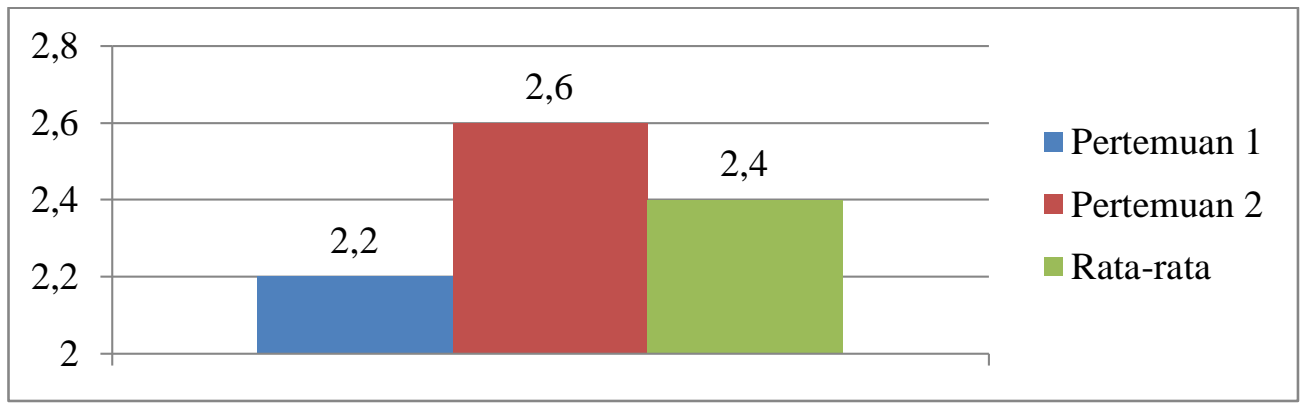

Gambar 1. Grafik Skor Rata-Rata Aktivitas Siswa Pada Siklus I

(Analisis Data Primer, 2019)

Berdasarkan gambar di atas dapat diperoleh gambaran bahwa hasil aktivitas belajar siswa tersebut masih belum memenuhi kriteria ketuntasan minimal yaitu 3,0, karena rata-rata aktivitas belajar siswa masih mencapai rata-rata 2,4 yang berkategori cukup. Dimana pada siklus I aktivitas siswa yang mendapat skor terendah dengan nilai rata-rata sebesar 2 adalah aktivitas belajar nomor 8, 10 dan 11 yaitu siswa menyimak dan menanggapi hasil diskusi kelompok lain, siswa bertanya mengenai materi yang belum atau kurang dipahami dan siswa menyimpulkan materi secara singkat, sedangkan aktivitas siswa yang mendapatkan skor tertinggi dengan nilai rata-rata sebesar 2,9 adalah aktivitas belajar nomor 3 dan 4 yaitu siswa mencari kelompok masing-masing yang telah dibagi oleh guru, siswa menerima dan mencoba memahami LKS dan membuat catatan kecil untuk didiskusikan dengan teman kelompok.

\section{Aktivitas Mengajar Guru Pertemuan I dan II Siklus I}

Gambaran rata-rata aktivitas guru selama pembelajaran pada siklus I pertemuan I dan II dapat dilihat pada gambar 2 berikut: 
Trisna Wati, 2019, Penerapan Model Pembelajaran Ttw (Think Talk Write) Dalam Meningkatkan Hasil Belajar Siswa Kelas X Iis 1 Sma Negeri 2 Kulisusu Pada Mata Pelajaran Geografi

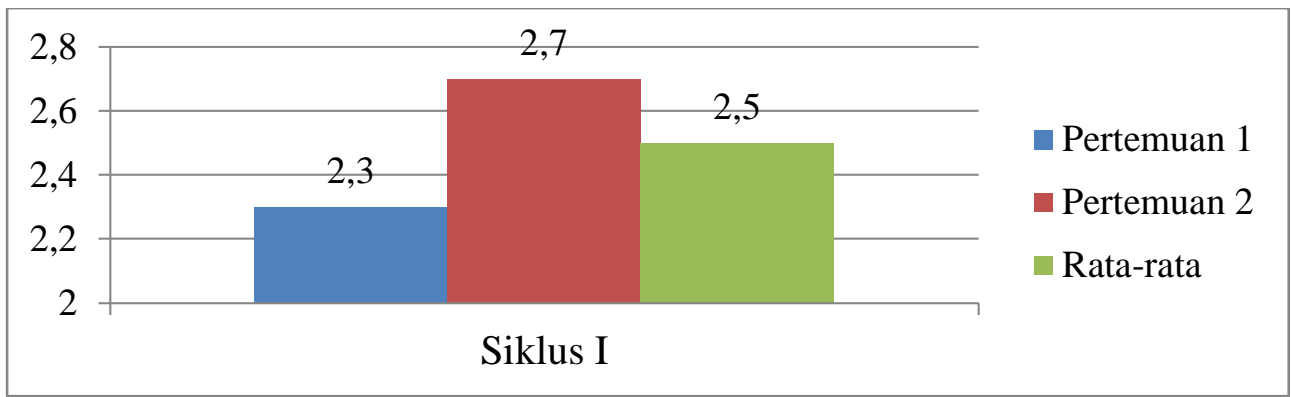

Gambar 2. Grafik Skor Rata-Rata Aktivitas Guru Siklus I (Analisis Data Primer, 2019)

Berdasarkan gambar di atas tentang hasil observasi aktivitas guru dapat diperoleh gambaran bahwa, hasil aktivitas guru tersebut masih belum memenuhi kriteria ketuntasan minimal yaitu 3,0, karena rata-rata aktivitas guru masih mencapai rata-rata 2,5 yang berkategorikan cukup.

\section{Hasil Belajar Siswa Pertemuan I dan II Siklus I}

Berdasarkan data hasil belajar siswa pada siklus I diperoleh analisis ketuntasan belajar siswa sebagaimana disajikan pada tabel berikut:

Tabel 1. Data Anlisis Ketuntasan Hasil Belajar Siswa Pada Siklus I

\begin{tabular}{lccc}
\hline \multicolumn{1}{c}{ Skor } & Jumlah Siswa & Presentase & Ketuntasan Belajar \\
\hline $0-74$ & 10 orang & $32,25 \%$ & Belum Tuntas \\
$75-100$ & 21 orang & $67,75 \%$ & Sudah Tuntas \\
\hline Jumlah & 31 orang & $\mathbf{1 0 0 \%}$ & \\
\hline & & Keterangan & 10 orang \\
Tidak Tuntas & & 21 orang \\
Tuntas & & 75,3 \\
Nilai rata-rata & & 90 \\
Nilai Maksimum & & 50 \\
Nilai Minimum & & $\mathbf{6 7 , 7 5 \%}$ \\
\hline Presentase Ketuntasan & &
\end{tabular}

Sumber:Analisis Data Primer, 2019.

Data di atas menunjukkan bahwa ketuntasan belajar siswa pada siklus I yang memperoleh skor antara 0-74 berjumlah 10 orang dengan presentase $32,25 \%$, sedangkan siswa yang telah memperoleh skor antara 75-100 berjumlah 21 orang dengan presentase 67,75\%, namun belum mencapai indikator ketuntasan keberhasilan dimana $80 \%$ siswa mencapai ketuntasan belajar. Untuk lebih jelasnya dapat dilihat pada gambar 3 berikut: 
Trisna Wati, 2019, Penerapan Model Pembelajaran Ttw (Think Talk Write) Dalam Meningkatkan Hasil Belajar Siswa Kelas X Iis 1 Sma Negeri 2 Kulisusu Pada Mata Pelajaran Geografi

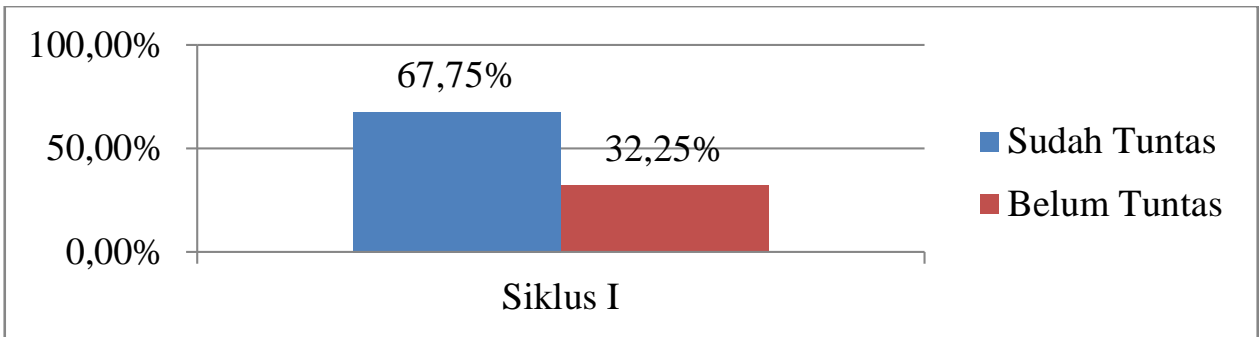

Gambar 3. Presentase Ketuntasan Hasil Belajar Siswa Siklus II (Analisis Data Primer, 2019)

Setelah mengetahui kekurangan yang terjadi pada siklus I baik itu yang dilakukan oleh guru maupun siswa, maka pada pembelajaran siklus II guru akan memperbaiki kesalahankesalahan yang dilakukan sebelumnya, sehingga hasil belajar dengan menerapkan model pembelajaran $T T W$ sesuai dengan indikator keberhasilan yang diharapkan yaitu mencapai ketuntasan hasil belajar siswa minimal $80 \%$.

\section{Pelaksanaa Tindakan Siklus II}

\section{Aktivitas Belajar Siswa Pertemuan I dan II Siklus II}

Gambaran rata-rata aktivitas belajar siswa selama pembelajaran pada siklus II pertemuan I dan II dapat dilihat pada gambar 4 berikut:

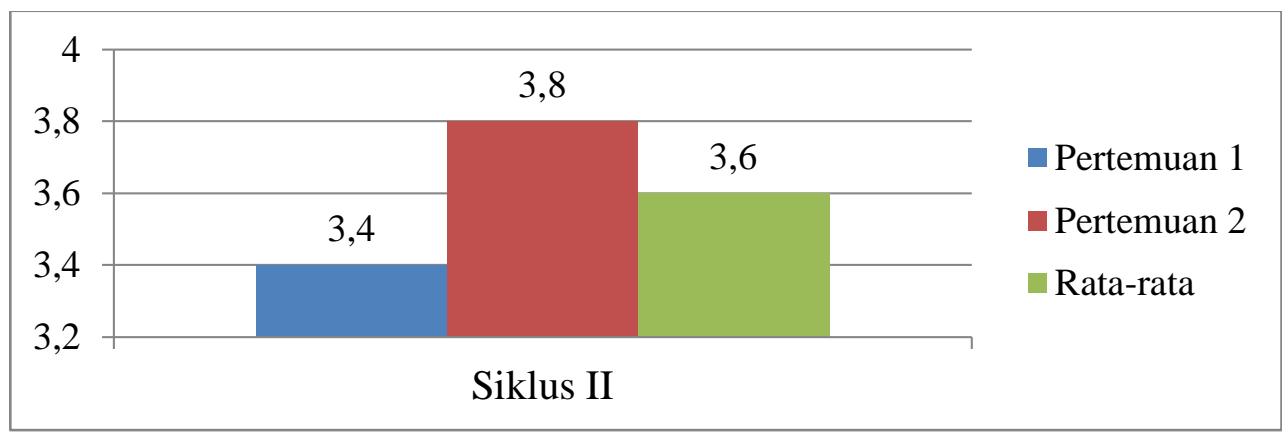

Gambar 4. Grafik Skor Rata-Rata Aktifitas Siswa Siklus II Pertemuan I dan II

(Analisis Data Primer, 2019)

Berdasarkan Gambar 4 diatas menunjukkan bahwa aktivitas belajar siswa telah memenuhi kriteria ketuntasan minimal yaitu 3,0. Dimana aktivitas belajar siswa telah mencapai rata-rata 3,6 yang berkategorikan baik.

\section{Aktivitas Mengajar Guru Pertemuan I dan II Siklus II}

Gambaran rata-rata aktivitas guru selama pembelajaran pada siklus II pertemuan I dan II dapat dilihat pada gambar 5 berikut: 
Trisna Wati, 2019, Penerapan Model Pembelajaran Ttw (Think Talk Write) Dalam Meningkatkan Hasil Belajar Siswa Kelas X Iis 1 Sma Negeri 2 Kulisusu Pada Mata Pelajaran Geografi

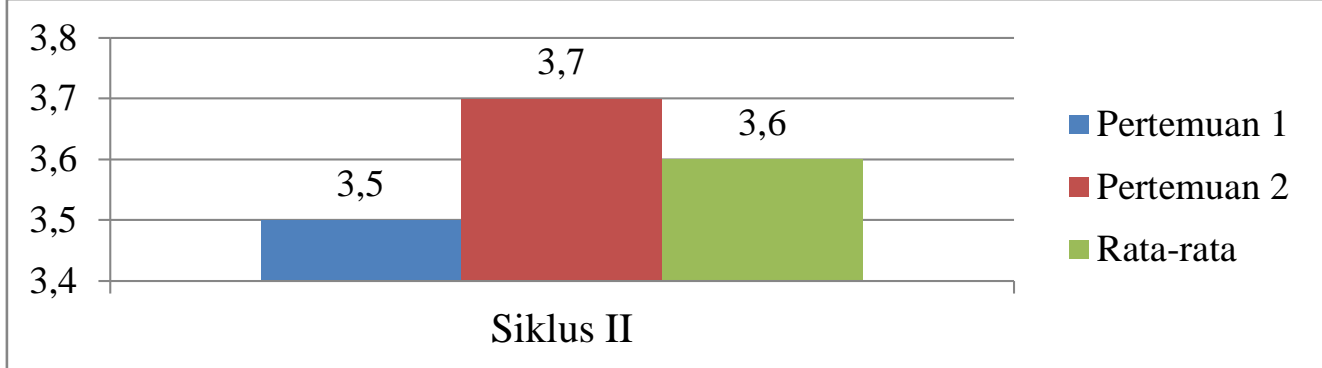

Gambar 5. Grafik Skor Rata-rata Aktivitas Guru Pada Siklus II

(Analisis Data Primer, 2019)

Berdasarkan gambar 5 diatas menunjukkan bahwa, aktivitas guru telah memenuhi kriteria ketuntasan minimal yaitu 3,0. Dimana aktivitas guru telah mencapai rata-rata 3,6 yang berkategori baik.

\section{Hasil Belajar Siswa Pertemuan I dan II Siklus II}

Hasil belajar siswa pada siklus II diperoleh melalui tes yang diberikan di akhir pertemuan siklus dan dapat dilihat melalui tabel berikut:

Tabel 2. Data anlisis ketuntasan hasil belajar siswa pada siklus II.

\begin{tabular}{lccc}
\hline \multicolumn{1}{c}{ Skor } & Jumlah Siswa & Presentase & Ketuntasan Belajar \\
\hline $0-74$ & 3 orang & $9,68 \%$ & Belum Tuntas \\
$75-100$ & 28 orang & $90,32 \%$ & Sudah Tuntas \\
Jumlah & 31 orang & $\mathbf{1 0 0 \%}$ & \\
\hline & & Keterangan & 3 orang \\
\hline Tidak Tuntas & & 28 orang \\
Tuntas & & 81,3 \\
Nilai rata-rata & & & 90 \\
Nilai Maksimum & & 66 \\
Nilai Minimum & & & \\
\hline
\end{tabular}

Presentase Ketuntasan

$90,32 \%$

Sumber Analisis Data Primer, 2019

Untuk lebih jelasnya mengenai gambaran hasil belajar siswa kelas X IIS 1 yang diajar dengan menggunakan model pembelajaran TTW pada siklus II dapat dilihat pada gambar 6 berikut: 

Siswa Kelas X Iis 1 Sma Negeri 2 Kulisusu Pada Mata Pelajaran Geografi

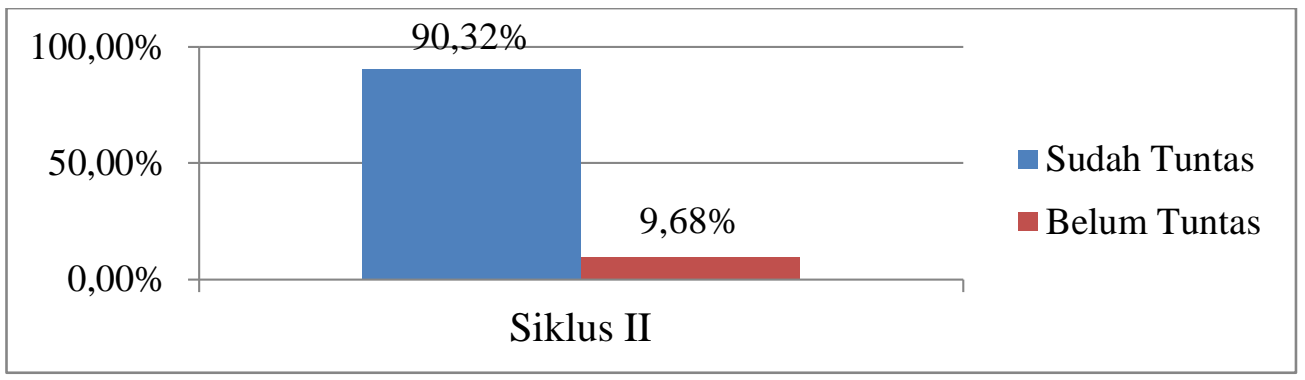

Gambar 6. Data Peningkatan Hasil Belajar Siswa Pada Siklus II (Analisis Data Primer, 2019)

Berdasarkan gambar 6 diatas menunjukkan bahwa ketuntasan belajar siswa pada siklus II yang memperoleh skor antara 0-74 berjumlah 3 orang dengan presentase 9,68 \%, sedangkan siswa yang telah memperoleh skor antara 75-100 berjumlah 28 orang dengan presentase ketuntasan mencapai 90,32 \%. Hasil ini sudah lebih baik jika dibandingkan dengan skor perolehan siswa pada siklus I. Oleh karena indikator ketuntasan belajar siswa telah tercapai, maka dikatakan hasil penelitian telah tercapai dan berhasi.

\section{PEMBAHASAN}

\section{Aktivitas Belajar Siswa}

Berdasarkan permasalahan pertama "Bagaimana gambaran aktivitas siswa melalui penerapan model pembelajaran Think Talk Write pada kelas X IIS 1 SMA Negeri 2 Kulisusu" dapat dijelaskan hasil pengamatan pada setiap siklus baik siklus I maupun siklus II menunjukan peningkatan kearah yang lebih baik. Peningkatan aktivitas belajar siswa tersebut menunjukan adanya minat dan antusias siswa dalam mengikuti proses pembelajaran pada materi pokok dinamika atmosfer dan dampaknya terhadap kehidupan dengan menggunakan model pembelajaran TTW.

Pada siklus I berdasarkan analisis terhadap aktivitas belajar siswa menunjukan skor rata-rata aktivitas siswa pada siklus I sebesar 2,4 yang berkategori cukup. Berdasarkan hasil refleksi ditemukan adanya beberapa aktivitas siswa yang masih belum terlaksana dengan baik seperti aktivitas nomor 8 yaitu siswa menyimak dan menanggapi hasil diskusi kelompok lain, berkategori cukup. Aktivitas nomor 10 yaitu siswa bertanya mengenai materi yang belum atau kurang dipahami, dengan kategori cukup. Aktivitas nomor 11 yaitu siswa menyimpulkan materi secara singkat, dengan ketegori cukup. Oleh karena itu dilakukan perbaikan pada siklus II.

Pada siklus II dari hasil analisis terhadap skor rata-rata aktivitas belajar siswa pada siklus II menunjukan adanya peningkatan yang signifikan dari aktivitas belajar siswa siklus I, dimana skor rata-rata aktivitas belajar siswa pada siklus II sebesar 3,6 dengan kategori baik. Hal ini menunjukkan bahwa penelitian telah berhasil karena telah memenuhi standar minimal aktivitas belajar siswa yaitu 3,0

\section{Aktivitas Mengajar Guru}

Berdasarkan permasalahan kedua yaitu "Bagaimana gambaran aktivitas mengajar guru melalui penerapan model pembelajaran Think Talk Write pada kelas X IIS 1 SMA Negeri 2 
Kulisusu" dapat dijelaskan berdasarkan hasil pengamatan pada setiap siklus I maupun siklus II yang menunjukan peningkatan kearah yang lebih baik.

Pada siklus I berdasarkan analisa aktivitas guru menunjukan skor rata-rata mengajar guru sebesar 2,5 yang berkategori cukup dimana aktivitas guru pada siklus I masih tergolong rendah. Pada siklus I menunjukan adanya aktivitas guru yang belum terlaksana dengan baik, (1) guru melakukan apersepsi tentang materi yang akan dipelajari berkategori cukup, (2) guru memberikan motivasi kepada siswa bertkategori cukup (3) guru membantu siswa dan mengorganisasikan siswa untuk belajar dan berdiskusi untuk memecahkan masalah yang terdapat pada LKS berkategori cukup, (4) guru melakukan refleksi terhadap hasil diskusi yang telah dipresentaskan oleh tiap-tiap kelompok berkategori cukup, (5) guru memberikan kesempatan kepada siswa dalam menyimpulkan materi berkategori cukup.

Berdasarkan hasil refleksi terhadap aktivitas guru, maka dengan mengetahui kekurangan-kekurangan pada siklus I, guru memperbaiki cara mengajarkan materi pembelajaran yang sesuai dengan model pembelajaran TTW, sehingga diharapkan pada pertemuan selanjutnya diperoleh peningkatan aktivitas guru pada siklus selanjutnya.

Pada siklus II aktivitas mengajar guru menunjukkan peningkatan, dimana pada siklus II skor rata-rata aktivitas guru memperoleh nilai sebesar 3,6 yang berkategori baik. Hasil analisis dan pengamatan pada siklus tersebut menunjukkan adanya peningkatan aktivitas guru melalui penerapan model pembelajaran TTW. Hal tersebut menunjukkan bahwa penelitian telah berhasil karena memenuhi standar minimal aktivitas mengajar guru yaitu 3,0.

\section{Hasil Belajar Siswa}

Berdasarkan hasil analisis hasil belajar siswa melalui test pada siklus I diperoleh nilai minimum sebesar 50, nilai maksimum sebesar 90, nilai rata-rata sebesar 75,3. Pada siklus ini secara keseluruhan belum memenuhi kriteria ketuntasan, dimana dari 31 siswa terdapat 21 siswa yang mencapai ketuntasan atau $67,75 \%$ yang mencapai nilai $\geq 75$ sesuai dengan KKM, dan terdapat 10 orang siswa dengan persentase sebesar 32,25\% siswa yang mencapai nilai $<75$ atau belum mencapai KKM. Persentase ketuntasan pada siklus ini belum mencapai ketuntasan secara keseluruhan yaitu sebesar $80 \%$. Rendahnya hasil belajar siswa ini disebakan karena siswa dan guru belum terbiasa dengan model pembelajaran TTW.

Studi lain yang dilakukan oleh Meri Azrah (2017) menunjukkan bahwa diperoleh nilai rata-rata hasil belajar peserta didik adalah 79,68 dan ketuntasan belajar mencapai 90,32\%. Hasil tersebut menunjukkan bahwa, secara klasikal peserta didik tuntas belajar, karena peserta didik yang memperoleh nilai sebesar 90,32. Ini lebih besar dari presentase ketuntasan yang dikehendaki yaitu sebesar $80 \%$. Adanya perbedaan hasil penelitian tersebut disebabkan dalam penerapan model pembelajaran TTW, peneliti belum mengoptimalkan penggunaan model pembelajaran TTW dalam proses pembelajaran sehingga membuat peserta didik kurang tertarik dalam pembelajaran. Sedangkan studi yang dilakukan oleh Meri Azrah (2017), dalam proses pembelajarannya dengan menggunakan model pembelajaran TTW sudah mengoptimalkan model pembelajaran TTW dalam proses pembelajarannya, sehingga membuat minat dan antusiasme siswa dalam proses pembelajaran meningkat. 
Berdasarkan refleksi dengan melihat aktivitas siswa dan hasil belajar pada siklus I tersebut, dapat diambil suatu kesimpulan bahwa dalam proses pembelajaran tampak bahwa siswa kurang antusias. Hal tersebut ditunjukkan dengan kurangnya siswa dalam menyimak dan menanggapi hasil diskusi kelompok lain pada kategori cukup, siswa bertanya mengenai materi yang belum atau kurang dipahami pada kategori cukup, siswa menyimpulkan materi secara singkat pada kategori cukup.

Setelah melakukan analisis dan refleksi hasil belajar siswa pada siklus I, guru mata pelajaran dan peneliti mencoba melakukan perbaikan dalam proses belajar mengajar agar pada siklus selanjutnya siswa yang memenuhi ketuntasan belajar dapat meningkat seperti yang diharapkan.

Hasil belajar siswa pada siklus II, menunjukan nilai rata-rata sebesar 81,3 dengan nilai minimum sebesar 66 dan nilai maksimum sebesar 90. Pada siklus II Hasil belajar telah memenuhi kriteria ketuntasan secara keseluruhan, dimana dari 31 siswa terdapat 28 siswa dengan presentase sebesar $90,32 \%$ yang mencapai nilai $\geq 75$ sesuai dengan $\mathrm{KKM}$, dan terdapat 3 orang siswa dengan persentase sebesar 9,68\% siswa yang belum mencapai KKM. Dari hasil yang diperoleh tersebut, menunjukan ada peningkatan hasil belajar siswa dari siklus I ke siklus II. Hasil tersebut sejalan dengan hasil penelitian yang dilakukan oleh Meri Azrah (2017) yaitu adanya peningkatan dari siklus I ke siklus II, dimana diperoleh nilai rata-rata hasil belajar peserta didik adalah 79,68 dan ketuntasan belajar mencapai 90,32\%.

Berdasarkan hal tersebut maka jawaban atas permasalahan penelitian telah terungkap yaitu pembelajaran melalui penerapan model pembelajaran TTW berhasil dalam meningkatkan aktivitas belajar siswa, aktivitas mengajar guru dan juga meningkatkan hasil belajar geografi siswa kelas X IIS 1 SMA Negeri 2 Kulisus khususnya pada materi pokok dinamika atmosfer dan dampaknya terhadap kehidupan.

\section{SIMPULAN DAN SARAN}

\section{Kesimpulan}

Dari penelitian yang telah dilakukan di SMAN 2 dengan menggunakan model pembelajaran TTW pada mata pelajaran geografi dapat disimpulkan bahwa:

1. Aktivitas belajar siswa dengan menerapkan model pembelajaran TTW pada setiap siklus cenderung meningkat, dimana pada siklus I skor rata-rata aktivitas siswa adalah 2,4 yang termasuk kategori cukup meningkat pada siklus II menjadi 3,6 yang termasuk pada kategori baik.

2. Aktivitas mengajar guru dengan menerapkan model pembelajaran TTW pada setiap siklus cenderung meningkat, dimana pada siklus I skor rata-rata aktivits guru adalah 2,5 yang termasuk kategori cukup dan meningkat pada siklus II menjadi 3,6 yang berkategori baik.

3. Terjadi peningkatan hasil belajar geografi siswa kelas X IIS 1 SMAN 2 Kulisusu dari siklus I ke siklus II sebesar 22,57\%. Dimana pada siklus I yaitu diperoleh nilai terendah 50, nilai tertinggi 90, nilai rata-rata 75,3 dan ketuntasan belajar sebesar 67,75\% atau hanya 21 siswa yang memperoleh nilai $\geq 75$. Pada siklus II diperoleh nilai terendah 66 , nilai tertinggi 90 , nilai rata-rata adalah 81,3 dan ketuntasan belajar pada siklus II mengalami peningkatan yaitu dari 31 orang siswa ada 28 orang siswa yang yang memperoleh nilai $\geq 75$, dengan persentase ketuntasan hasil belajar adalah $90,32 \%$. Hal ini telah melampaui target yang ditentukan yakni $80 \%$ indikator ketuntasan belajar. 
Trisna Wati, 2019, Penerapan Model Pembelajaran Ttw (Think Talk Write) Dalam Meningkatkan Hasil Belajar Siswa Kelas X Iis 1 Sma Negeri 2 Kulisusu Pada Mata Pelajaran Geografi

\section{Saran}

Berdasarkan kesimpulan diatas, maka peneliti menyarankan hal-hal sebagai berikut:

1. Bagi sekolah khususnya SMA Negeri 2 Kulisusu kelas X IIS bahwa model pembelajaran Think Talk Write dapat dijadikan salah satu alternatif dalam meningkatkan hasil belajar geografi siswa pada materi pokok dinamika atmosfer dan dampaknya terhadap kehidupan.

2. Bagi guru SMA Negeri 2 Kulisusu, khususnya guru mata pelajaran geografi lebih memperdalam pemahaman tentang penelitian tindakan kelas, agar masalah-masalah yang dialami siswa dalam proses pembelajaran dapat diatasi

\section{DAFTAR RUJUKAN}

Agung, Iskandar. 2012. Panduan Penelitian Tindakan Kelas bagi Guru. Jakarta: PT Bestari Buana Murni.

Azrah, Meri. 2017. Penerapan Strategi Think Talk Write (TTW) Dalam Pembelajaran Kooperatif Untuk Meningkatkan Hasil Belajar Matematika Siswa Kelas III SD Negeri 009 Tembilahan. Jurnal Primary Progtam Studi Pendidikan Guru Sekolah Dasar Fakultas Keguruan Dan Ilmu Pendidikan Universiras Riau. Vol. 6. No.1.

Hamdayana, Jumanta. 2014. Model dan Metode Pembelajaran Kreatif dan Berkarakter. Bogor: Ghalia Indonesia.

Huda, Miftahul. 2013. Modeo-model Pengajaran dan Pembelajaran. Yogyakarta: Pustaka Pelajar.

Rusman. (2013). Metode-Metode Pembelajaran: Mengembangkan Profesionalisme Guru. Jakarta: PT RajaGrafindo Persada

Slameto. 2011. Belajar dan factor-faktor yang Menpengaruhinya. Jakarta: Rajawali Pers.

Sudjana, Nana. (2011). Penilaian Hasil Proses Belajar Mengajar. Bandung: PT Remaja Rosdakarya.

Suhendar, E. 2011. Model Pembelajaran Think Talk Write. [Online]. Tersedia: http://fisikasmaonline.blogspot.com/2011/03/model-pembelajaran-ttw.html. [15 November 2018].

Susanto, Ahmad. 2013. Teori Belajar \& Pembelajaran di Sekolah Dasar. Jakarta: Prenada Media Group.

\section{Editor In Chief}

Erman Syarif

emankgiman@unm.ac.id

\section{Publisher}

Geography Education, Geography Departemenr, Universitas Negeri Makassar

Ruang Publikasi Lt.1 Jurusan Geografi Kampus UNM Parangtambung, Jalan Daeng Tata, Makassar.

Email : $\underline{\text { lageografia@unm.ac.id }}$

Info Berlangganan Jurnal

085298749260 / Alief Saputro 